УДК 903.27-033.5 (477.73)

DOI: https://doi.org/10.33782/eminak2019.1(25).213

\title{
СТЕКЛЯННЫЕ СОСУДЫ, ИЗГОТОВЛЕННЫЕ В ТЕХНИКЕ СЕРДЕЧНИКА ИЗ ОЛЬВИИ
}

\author{
Анжелика Колесниченко \\ Институт археологии Национальной академии наук Украины (Киев, Украина) \\ e-mail: magtaban1984@gmail.com \\ ORCID: https://orcid.org/0000-0002-4598-5929
}

У статті надано загальну характеристику скляних посудин закритих форм з Ольвії. Аналіз контекстів дозволив простежити динаміку їх використання та закономірності розподілу знахідок у просторі міста. Набір форм посудин відображає їх еволюцію протягом усього періоду виготовлення.

Ключові слова: Північне Причорномор'я, Середземномор'я, теменос, контекст, техніка сердечника

Стеклянные сосуды, изготовленные в технике сердечника - характерная продукция стеклоделия ранней античности. Прекрасные образцы этих предметов прикладного искусства известны из многих древнегреческих некрополей. Однако, мало изученными остаются иные аспекты их применения в живой культуре эллинов. Так, в Средиземноморье описаны находки таких флаконов в сакральных комплексах1. Отдельные работы освещают сосуды из производственных контекстов². Общепризнана их роль в качестве тары для благовоний и ароматических масел‥ При этом, вопросы возможных отличий в наборе форм и разновидностей сосудов, в динамике их использования в зависимости от сферы использования (сакральной, торговопроизводственной, погребальной и т.д.) не только не рассматривались, но и не ставились. Публикации обычно ограничиваются рассмотрением типологического набора сосудов без контекстуального анализа или же наоборот, фокусируются на отдельных небольших коллекциях из четко выраженных контекстов - некрополей, храмов, мастерских.

Достаточную источниковедческую базу для такого сравнения могут предоставить немногие античные центры. Одним из них является Ольвия. Тут известны как выразительные материалы некрополя, так и находки из жилых кварталов, района агоры и сакральных комплексов - теменосов.

В настоящее время Ольвия является эталонным памятником для изучения стеклянных сосудов VI-I вв. до н.э. На фоне всех Северопонтийских центров она выгодно отличается как количеством находок, так и разнообразием исследованных контекстов. В результате многолетних раскопок с конца XIX в. до сегодня были исследованы

\footnotetext{
1 Stern E.M. Ancient Glass in Athenian Temple Treasures // Journal of Glass Studies. 1999. Vol. 41. P. $37-$ 40; Nenna M.-D. Les contenants à huile parfumée façonnés sur noyau dans les dépôts votifs des sanctuaires grecs: l’exemple de l'Artémision de Thasos // Annales du 18 Congrès de l'Association Internationale pour l'Histoire du Verre. 2012. P. 61-68.

2 Weinberg G.D. Glass manufacture in the Hellenistic Rhodes //Archaiologikon Deltion. 1969. Vol. 24. P. 143-151; Ignatiadou D. Early glass in Methone // Annales du 19e Congrès de I'Association Internationale pour l'Histoire du Verre. 2012. P. 81-88.

3 Fossing P. Glass Vessels before Glass-Blowing. Copenhagen, 1940. P. 75-76.
} 
многие структурные части античного города4. Это позволяет изучить стеклянные сосуды в разнотипных контекстах и дать им сравнительную характеристику по числу и составу форм, динамике поступления. На основе находок Ольвии есть возможность изучить значение стеклянных сосудов в разных сферах жизни населения античных центров.

Публикации стекла VI-I вв. до н.э. Ольвии носят неполный характер и, как правило, касаются материалов отдельных участков. В научный оборот введена информация о стеклянных сосудах, найденных на участках НГС (Нижнего города) 5 , АГД (Западный теменос)6, Р-25 (Южный теменос) ${ }^{7}$ и происходящих из некрополя Ольвии 8 .

По последним данным количество находок составляет около 280 экземпляров, из них 40 целых флаконов9. Подсчеты охватывают как сосуды из музейных коллекций без точного контекста находки, так и экземпляры, обнаружение которых засвидетельствовано лишь только упоминанием в полевой документации. Статистика обнаружения вещей зависит от площади исследованных участков, насыщенности слоя, количества и характера объектов, а также от методики исследования ${ }^{10}$. Наибольшее количество целых и фрагментированных сосудов было найдено в результате исследований Б.В. Фармаковского в начале ХХ в., преимущественно на некрополе, и раскопок во второй половине 1940-х гг. Современные раскопки с начала XXI в. в среднем приносят по 2-6 сосудов в год, что отражает систематическое присутствие флаконов в черте города. Источниковедческую базу дополняют вещи из музейных коллекций Украины, Германии, которые были куплены у частных лиц в конце XIX - начале XX вв.11

Хронология и пространственное распределение находок. В этом разделе будет рассмотрено распределение находок по участкам Ольвии, восстановленное по полевой документации. Оно отображено графически на плане раскопок Ольвии, составленном С.Д. Крыжицким и А.В. Карякой 12 (рис. 1).

Структура полиса предполагает пространственную дифференциацию различных аспектов жизни ольвиополитов. Поэтому, разнообразные и многочисленные контексты обнаружения сердечниковых сосудов могут быть сгруппированы в катего-

\footnotetext{
4 Крыжицкий С.Д. Ольвия. Историографическое исследование архитектурно-строительных комплексов. Киев, 1985.

${ }^{5}$ Puklina O. Glass objects // The Lower city of Olbia (Sector NGS) in the $6^{\text {th }}$ century BC to the $4^{\text {th }}$ century AD. Aarhus, 2010. Vol. 1. P. 487-497.

${ }^{6}$ Скржинская М.В. Стеклянные и пастовые изделия // Материалы по археологии, истории и этнографии Таврии. Древнейший теменос Ольвии Понтийской. Suppl. 2006. Вып. 2. С. 206-208.

7 Колесниченко А.М. Скляний посуд доримського часу з розкопок Південного теменосу Ольвії Понтійської // Північне Причорномор'я за античної доби (на пошану С.Д. Крижицького). Київ, 2017. C. 64-81.

${ }^{8}$ Колесниченко А.Н. Стеклянные сосуды конца VI - нач. V в. до н.э., изготовленные в технике сердечника, из некрополя Ольвии в районе Широкой Балки // Стародавнє Причорномор'я. 2016. Вип. XI. С. 261-268; Скуднова В.М. Архаический некрополь Ольвии. Ленинград, 1988. 180 с.

9 По данным полученным после прочитанного доклада 4-6 мая 2018 года.

10 Колесниченко А.Н.Стеклянные сосуды, изготовленные в технике сердечника из Ольвии // FORUM OLBICUM II: Памяті B.В. Крапівіної (до 150-річчя дослідженняОльвії), 4-6 травня 2018 р. Миколаїв, 2018. Рис. $1,1$.

${ }^{11}$ Saldern A., Nolte B., La Baume P., Haevernick T.E. Gläser der Antike. Sammlung Oppenländer. Hamburg, 1974. Cat. 129, 164, 177, 181, 186, 191, 220; Колесниченко A.М. Скляні флакони VI-I ст. до н.е. 3 Одеського археологічного музею НАНУ: Історія формування колекції та її типологічна структура // Записки історичного факультету. 2017. Вип. 28. С. 48-51

12 Крижицький С.Д., Каряка О.В. До історії створення загального плану архітектурно-будівельних залишків Ольвії // Археологія. 2017. № 3. С. 66-80
} 
рии общего функционального характера. В этом смысле содержательно рассматривать отдельно погребальные, храмово-сакральные, публичные и жилые контексты.

Некрополь Ольвии принес наибольшее количество сердечниковых сосудов в сравнении с другими типами контекстов. Они использовались в погребальных ритуалах с VI по I в. до н.э.13 Таким образом, в Ольвии существовала устойчивая традиция помещения в могилу стеклянных флаконов в качестве погребального инвентаря. 40\% всех находок относится к периоду последняя четверть VI - первая половина $\mathrm{V}$ в. до н.э., четверть экземпляров датируется V в. до н.э., редкие сосуды (6) относятся к III-II вв. до н.э. (рис. 1).

В контекстах, связанных с повседневной жизнью горожан, выразительные серии сосудов, изготовленных в технике сердечника, найдены на участках И, НГ, НГС, НГФ, T-3, «Зевсов курган», Некрополь-4 (предместье). На участке «Зевсов курган» больше половины сосудов найдено в комплексах позднеэллинистического времени. Участок «И» с эллинистическими объектами характеризуется наличием только 3 определимых экземпляров (2 - V в., 1 - III-II вв. до н.э.). Напротив, на участке НГС 50\% находок относится к V в. до н.э. (рис. 1 ).

Отдельные комплексы содержали серии находок сердечникового стекла. Так, на участке «Некрополь-4» (предместье) была выявлена полуземлянка № $16^{14}$. В ней обнаружены 7 обломков от 6 сосудов, а также много бус. Все наличные здесь сосуды датируются одним хронологическим диапазоном - последней четвертью VI - началом V вв. до н.э. Это самая значительная серия сердечниковых сосудов, которая когда-либо была найдена в одном комплексе из Ольвии. Это исключительное количество стеклянных изделий связано с предполагаемым особым статусом полуземлянки, который требует отдельной интерпретации. Так, возможны предположения о торговом («пункт сбора вторсырья») или сакральном характере. Подобный объект с находками обломков сосудов и бус VI-V вв. до н.э. исследован на агоре в Македонской Мефони. Предложенная Д. Игнатиаду интерпретация связывает его с функционированием мастерской по производству стеклянных бус и сосудов ${ }^{15}$. Хотя изготовление сосудов в Мефони может быть поставлено под сомнение, вряд ли можно отрицать стеклообработку с целью получения бус в вышеупомянутом комплексе. Эта аналогия является аргументом в пользу торгово-производственного назначения ольвийской полуземлянки № 16. Она действительно может быть местом сбора обломков сосудов для вторичной обработки.

Сакральная сфера жизни ольвиополитов нашла наиболее полное отражение в материалах теменосов и зон святилищ. Как известно, в Ольвии функционировали три теменоса - Восточный (участок E) ${ }^{16}$ и Западный (участок АГД) ${ }^{17}$ и Южный теме-

\footnotetext{
13 Скуднова В.М. Архаический некрополь Ольвии. Ленинград, 1988. С. 30-31; Козуб Ю.І. Некрополь Ольвії V-IV ст. до н.е. Київ, 1974. С. 81.

14 Буйских А.В., Форнасье Й., Кузьмищев А.Г. Предместье Ольвии в свете новых украинскогерманских исследований // Записки Института истории материальной культуры РАН. 2016. № 14. C. 51-54.

15 Ignatiadou D. Early glass in Methone // Annales du 19e Congrès de l'Association Internationale pour I'Histoire du Verre. Thessaloniki, 2015. P. 84-85.

16 Леви Е.И. Материалы ольвийского теменоса. (Общая характеристика) // Ольвия. Теменос и агора. Москва-Ленинград. С. 131-174.

17 Rousyaeva A.S. Sanctuaries in the Context of the Cultural and Historical Development of Olbia Pontica. // Ancient Sacral Monuments in the Black Sea. Thessaloniki, 2010. P. 63-92.
} 
носы (участок Р-25)18. Исследование зоны последнего продолжаются до сегодняшнего дня.

На Западном теменосе преобладают сосуды, отнесенные к двум частично пересекающимся хронологическим диапазонам: конца VI - начала V вв. до н.э. и V в. до н.э. На Восточном теменосе доступной для определения оказалась лишь половина находок: большая часть из которых относится к V-IV вв. до н.э. Максимальное количество обломков стеклянных сосудов было обнаружено в Южном теменосе (рис. 1).

Чуть более 65\% всех сосудов относятся к концу VI - первой четверти V в. до н.э. Вторая-третья четверть V в. до н.э. - период бытования следующей немногочисленной группы изделий ${ }^{19}$. Такая динамика использования сосудов предположительно может отражать этапы создания и перестройки храмов в рамках священной зоны ${ }^{20}$.

Стеклянные сосуды, яркие произведения прикладного искусства естественным образом находили свое место в культово-обрядовой жизни древнегреческих поселений. Контейнеры для благовоний постоянно применялись при обрядовых действиях. Поэтому, зафиксированы находки фрагментов сердечниковых сосудов в вотивных кладах и ботросах при храмах и в священных зонах на многочисленных памятниках Средиземноморья на протяжении всего периода их изготовления 21.

Преобладание в Западном и Южном теменосах Ольвии стеклянных сосудов конца VI - первой половины V в. до н.э. соответствует хронологической картине и на святилищах Греции, а именно в храме Геры на Делосе, Корикийской пещере на склонах Парнаса, в храме Артемиды на Тасосе и других святилищах 22 .

В совокупности находки в теменосах более многочисленны, чем сосуды и их фрагменты так или иначе связанные с жилыми или общественными постройками.

Набор форм. Как нами отмечалось выше, изучено только 40 целых экземпляров, остальные сильно фрагментированы, что затрудняет их атрибуцию. В таких случаях применялся прием корреляции формы и стилистических особенностей сосуда, когда по отдельным его фрагментам можно предположить и его полную форму, в том числе указать с достаточной степенью достоверности на его принадлежность той или иной хронологической группе по классификации Д. Хардена и Д. Гроуза23. Ольвия является единственным памятником Северного Причерноморья, в котором установлен полный спектр форм стеклянных сосудов (рис. 2), изготовлявшиеся в технике сердечника. Самой распространенной формой являются алабастры 108 экз. Амфорисков найдено 50 сосудов, 10 - арибаллов, 2 - унгвентария, 1 - гидриск (рис. 3). Остальные фрагменты имеют слишком маленькие размеры или утрачены, что затрудняет установление их формы или датировки.

\footnotetext{
${ }_{18}$ Bujskikh A.V. The Southern Temenos in Pontic Olbia (Preliminary Results of the Investigation) // Ancient Civilizations from Scythia to Siberia. 2015. Vol. 21. P. 222-250.

19 Колесниченко А.М. Скляний посуд до римського часу з розкопок Південного теменосу Ольвії // Північне Причорномор'я за античної доби (на пощану С.Д. Крижицького). Київ, 2017. С. 73-74.

20 Буйских А.В. Южный теменос Ольвии Понтийской (предварительные итоги изучения) // ВДИ. 2015. № 2. С. 12-13.

21 Колесниченко А.Н. Стеклянные сосуды закрытых форм VI-I в. до н.э. в сакральных контекстах Средиземноморья и Северного Понта // Стародавнє Причорномор'я. 2018. Bип. XII. C. 291-298.

22 Nenna M.-D. Les contenants à huile parfumée façonnés sur noyau dans les dépôts votifs des sanctuaires grecs : l'exemple de l'Artémision de Thasos // Annales du 18e Congrès de l'Association Internationale pour l'Histoire du Verre. Thessaloniki, 2012. P. 61-63.

23 Grose D.F. The Toledo Museum of Art. Early Ancient Glass. Core-Formed, Rod-Formed, Cast Vessels and Objects from the Late Bronze Age to the Early Roman Empire (from 1600 B.C. to A.D. 50).N-Y., 1989; Harden D.B. Catalogue of Greek and Roman Glass in the British Museum. Vol. I. Core- and Rod-Formed Vessels and Pendants. London, 1981.
} 
Сравнение набора форм было проведено и по описанным выше типам контекстов (рис. 4). На некрополе, и в жилищно-бытовых контекстах преобладающей формой являются алабастры, а амфориски им значительно уступают по количеству экземпляров. В сакральных зонах же, наоборот, число амфорисков сопоставимо с количеством алабастров и в отдельных случаях превосходит последнее. К сожалению, неопределимые фрагменты составляют здесь процент достаточный для радикального изменения описанного паттерна в случае, если все они окажутся принадлежащими лишь к одной форме. Все же такая избирательность представляется маловероятной, поэтому можно предположить и содержательное объяснение такому распределению форм. Алабастры представляются нам контейнерами для благовоний действительно применявшимися для их повседневного и иного использования, частью вещей, которые индивидуум мог носить с собой. В качестве проекции этой их функции в загробную жизнь они попадали и в набор погребальных даров. Амфориски же были скорей связаны со «стационарным» хранением благовоний и ароматических масел, гораздо более вероятным в храмах и священных зонах. Видимо, они могли и переиспользоваться чаще чем алабастры.

В целом типологическое разнообразие сердечниковых сосудов из Ольвии представлено 19 типами алабастров, 8 - амфорисков, 6 - ойнохой, 2 - арибаллов, 1 - гидрисков и 1 - унгвентариев (рис. 2). Эта картина сопоставима с полным спектром типов сосудов, изготовленных в технике сердечника, в той мере, в которой они представлены в крупнейших центрах Средиземноморья. На северном побережье Понта Эвксинского это единственный памятник с таким разнообразием продукции. Некоторые экземпляры, такие как ранние алабастры и ойнохои из белого и синего стекла имеют редкие аналогии и позволяют соотносить эту продукцию с одним мастером²4. В Ольвии обнаружены сосуды, которые с большой вероятностью относятся к родосскому производству.

Для эллинистического периода гидриск из Ольвии является пока единственной находкой в Северном Причерноморье. Аналогии ольвийским унгвентариям зафиксированы только в Тире 25 .

Находки сосудов в закрытых комплексах Ольвии позволили сильно сузить их хронологию, для некоторых экземпляров до четверти столетия.

Общая динамика использования сердечниковых сосудов в Ольвии. Древнейшие сердечниковые сосуды поступают в Ольвию только в последней четверти VI в. до н.э. Флаконы, изготовленные в технике сердечника, исчезают, уступая свое место массовой продукции полученной с помощью выдувания, лишь в начале I в. н.е. Этот этап их использования также нашел свое отражение в ольвийской коллекции. Ввиду неравной длины хронологических диапазонов, к которым могут быть отнесены те или иные типы сосудов, динамику их поступления в город можно изучать исключительно в относительном (процентном) соотношении (рис. 5). Промежуток времени с последней четверти VI по первую четверть V в. до н.э. характеризуется максимальной интенсивностью (оцененной как соотношения числа датированных экземпляров к длительности промежутку времени в годах) поступления сосудов, изготовленных в технике сердечника, в город. Находки указанного периода в осно-

\footnotetext{
24 McClellan M.C. Core-formed glass from dated contexts // Unpublished PhD dissertation. University of Pennsylvania. University Microfilms International. Ann Arbor (UMI 8505107). Michigan, 1984. P. 31.

${ }_{25}^{25}$ Колесниченко А.М. Скляний посуд V ст. до н.е. - початок I ст. н.е. з розкопок Тіри // Археологія. 2018. № 1. C. 104.
} 
вном представлены на Западном и Южном теменосах Ольвии, а также на ее некрополе (рис. 1). К этой же хронологически ранней группе могут быть отнесены и недавние находки с предместья Ольвии (участок Некрополь-4).

Наибольшее же абсолютное число датированных сердечниковых сосудов приходится на V в. до н.э. (25 экз. датируются этим столетием «в целом», 12 - его первой половиной, 6 - второй). Эта же картина зафиксировано на всех участкам, которые принесли репрезентативные выборки стеклянных флаконов (рис. 5).

Уже в рамках V в. до н.э., если отбросить широко датированные экземпляры, можно проследить тенденцию к сокращению количества стеклянных сосудов. Еще более ярко этот тренд проявляется в ходе IV в. до н.э., а с середины III в. до н.э. наблюдается и почти полное их исчезновение. Такая ситуация соответствует общей периодизации развития города - максимум поступления совпадает с периодом стабильного экономического роста Ольвии в V в. до н.э., а кризис середины III - начала II в. до н.э. находит свое отражение в значительном снижении импорта дорогой стеклянной тары ${ }^{26}$.

Описанный выше относительный показатель аналогичен «годовому коэффициенту», применяемому для изучения динамики импорта амфорной тары ${ }^{27}$. Он показывает, сколько сосудов в среднем приходится на год. Этот относительный индекс отображает следующую динамику: последняя четверть VI - первая четверть V в. до н.э. - 1,3 сосуда в год; V в. до н.э. - 0,9 сосуда; IV - первая половина III в. до н.э. - 0,2 сосуда; середина III в. до н.э. - начало I в. н.э. - 0,05 сосуда. Таким образом, несмотря на то, что 44\% всех датированных вещей относятся к V в. до н.э., максимальная частота поступления приходится на конец VI - первую четверть V в. до н.э. - период активной планомерной застройки города, появления теменосов и агоры ${ }^{28}$.

Выводы. Коллекция из Ольвии - эталонная для изучения сосудов в технике сердечника Причерноморья. Исключительная типохронологическая вариативность сопровождается и разнообразием контекстов использования стеклянных флаконов. Кроме их применения в погребальном обряде надежно и всесторонне фиксируется употребление в храмах и теменосах (как обрядовых предметов, так и вотивных даров), в торговле и, наконец, в быту.

Ольвийская коллекция не только содержит почти полный набор типов, известных в Средиземноморье; ввиду многочисленности закрытых комплексов обнаружения, она является базовой для разработки типохронологии сердечниковых сосудов Причерноморья. В отдельных случаях именно хронология комплексов Ольвии позволяет значительно сузить датировку того или иного типа флаконов вплоть до четверти столетия не только для Причерноморья, а и для Средиземноморья, поскольку зарубежными авторами многие типы выделены в основном по беспаспортным экземплярам. В отличие от погребальных комплексов, где сосуды могли использоваться и значительно позднее времени их изготовления (как «бабушкин сервиз»), находки обломков в культовых и жилых комплексах указывают на реальное время их бытования в живой культуре.

\footnotetext{
${ }^{26}$ Крыжицкий С.Д. Ольвия. Историографическое исследование архитектурно-строительных комплексов. Киев, 1985. С. 172-173

27 Шелов Д.Б. Керамические клейма из Танаиса III-І вв. до н.э. Москва, 1975. С. 26; Брашинский И.Б. Методика исследования античной торговли. Ленинград, 1984. С. 128-131.

28 Крыжицкий С.Д. Ольвия: историографическое исследование архитектурно-строительных комплексов. Киев, 1985. С. 172
} 
Динамика поступления сосудов технике сердечника в Ольвию отражает общие тенденции их распространения в Средиземноморье и Причерноморье. Пик поступления сердечниковых сосудов в Ольвию приходится на начальный период их производства - на последнюю четверть VI - начало V вв. до н.э. В дальнейшем, относительная динамика их использования характеризуется медленным уменьшением вплоть до полного упадка и замещения их продукцией техники выдувания в начале I в. н.э.

\section{REFERENCES}

Brashinskii, I.B. (1984). Metody issledovaniia antichnoi torgovli (na primere Severnogo Prichernomoria) [Research Methods of Antique Trade (on the example of the Northern Black Sea Coast]. Leningrad: Nauka [in Russian].

Buiskikh, A.V. (2015). The Southern Temenos in Pontic Olbia (Preliminary Results of the Investigation). Ancient Civilizations from Scythia to Siberia, 21, 222-250 [in English].

Buiskikh, A.V. (2015). Yuzhnyi temenos Olvii Pontiiskoi (predvaritelnyie itogi izucheniia) [The Southeren Temenos of Olbia Pontica (Preliminary Results)]. Vestnik Drevnei Istorii, 2, 6-21 [in Russian].

Buiskikh, A.V., Fornasier, J. \& Kuzmishchev, A.G. (2016). Predmestie Olvii v svete novykh ukrainskogermanskikh issledovanii [Olbian Suburb in the light of New Ukrainian-German Studies]. Zapiski instituta istorii materialnoi kultury RAN, 14, 51-54 [in Russian].

Fossing, P. (1940). Glass Vessels before Glass-Blowing. Copenhagen: Ejnar Munksgaard [in Danish].

Grose, D.F. (1989). The Toledo Museum of Art. Early Ancient Glass. Core-Formed, Rod-Formed, Cast Vessels and Objects from the Late Bronze Age to the Early Roman Empire (from 1600 B.C. to A.D. 50). NewYork: Hudson Hills Press [in English].

Harden, D.B. (1981). Catalogue of Greek and Roman Glass in the British Museum. Vol. I. Core- and RodFormed Vessels and Pendants. London: The Trustees of the British Museum [in English].

Ignatiadou, D. (2015). Early glass in Methone. Annales du 19e Congrès de l'Association Internationale pour l'Histoire du Verre, 81-88 [in English].

Kolesnichenko, A.M. (2016). Stekliannye sosudy kontsa VI - nach. V v. do n.e., izgotovlennye v tekhnike serdechnika, iz nekropolia Olvii v raione Shirokoi Balki [Glass vessels late VI - early V centuries BC from necropolis of Olbia near Shyroka gully]. Starodavnie Prichornomoria, XI, 261-268 [in Russian].

Kolesnychenko, A.M. (2017). Skliani flakony VI-I st. do n.e. z Odeskoho arkheolohichnoho muzeiu NANU: Istoriia formuvannia kolektsii ta yii typolohichna struktura [Glass vessels VI-I centuries BC from Odessa Archaeological Museum of National Academy of Sciences of Ukraine: history of collection's formation and its typological structure]. Zapysky istorychnoho fakultetu, 28, 45-63 [in Ukrainian].

Kolesnychenko, A.M. (2017). Sklianyi posud do rymskoho chasu z rozkopok Pivdennoho temenosu Olvii [Pre-Roman Glass vessels from the excavation of the Southern Temenos of Olbia Pontica]. In Havryliuk, N.O. (Ed.). Pivnichne Prychornomoria za antychnoi doby (na poshchanu S.D. Kryzhytskoho) (pp. 64-81). Kyiv: Starodavnii svit [in Ukrainian].

Kolesnychenko, A.M. (2018). Sklianyi posud V-I st. do n.e. z rozkopok Tiry [Glass Vessels of the $5^{\text {th }}-1^{\text {st }}$ Centuries from Excavation of Tyras]. Arkheolohiia, 1, 102-111 [in Ukrainian].

Kolesnichenko, A.M. (2018). Stekliannye sosudy zakrytykh form VI-I v. do n.e. v sakralnykh kontekstakh Sredizemnomoria i Severnogo Ponta [Core-formed glass vessels in sacral contexts of Mediterranean and Northern Pontic regions (VI-I centuries BC)]. Starodavne Prychornomoria, XII, 291-298 [in Russian].

Kolesnichenko, A.M. (2018). Stekliannye sosudy, izgotovlennye v tekhnike serdechnika iz Olvii [Coreformed glass vessels from Olbia]. In Havryliuk, N.O. (Ed.). FORUM OLBICUM: Pamiati V.V. Krapivinoi (do 150-richchia doslidzhennia Olvii) 4-6 travnia 2018 r. (pp. 54-56). Mykolaiv: NDTs «Lukomorie» [in Russian].

Kozub, Yu.I. (1974). Nekropol Olvii V-IV st. do n.e. [Necropolis of Olbia V-IV BC]. Kyiv: Naukova dumka [in Ukrainian].

Kryzhytskyi, S.D. \& Kariaka, O.V. (2017). Do istorii stvorennia zahalnoho planu arkhitekturnobudivelnykh zalyshkiv Olvii [To History of Development the General Plan of Architectural and Building Remains at Olbian Hill-fort]. Arkheolohiia, 3, 66-80 [in Ukrainian].

Kryzhytskyi, S.D. (1985). Olviia. Istoriograficheskoe issledovanie arkhitekturno-stroitelnykh kompleksov [Olbia. Historiographical study on architectural complexes]. Kyiv: Naukova dumka [in Russian]. 
Kunina, N.Z. (1997). Antichnoe steklo v sobranii Ermitazha [Ancient glass in the Hermitage collection]. Sankt-Petersburg: ARS [in Russian].

Levi, E.I. (1964). Materialy olviiskogo temenosa (Obshchaia kharakteristika) [Materials of Olbian temenos. (General characteristics)]. In Gaidukevich, V.F. (Ed.), Olviia. Temenos i agora (pp. 131-174). Moscow-Leningrad: AN USSR [in Russian].

McClellan, M.C. (1984). Core-formed glass from dated contexts (PhD dissertation). University of Pennsylvania, Michigan. Retrieved from https://repository.upenn.edu/edissertations/995 [in English].

Nenna, M.-D. (2012). Les contenants à huile parfumée façonnés sur noyau dans les dépôts votifs des sanctuaires grecs: l'exemple de l'Artémision de Thasos. Annales du 18e Congrès de l'Association Internationale pour l'Histoire du Verre, 61-68 [in French].

Puklina, 0.0. (2010). Glass objects. In Lejpunskaja, N.A. (Ed.), Black Sea Studies 13. The Lower city of Olbia (Sector NGS) in the 6-th century BC to the 4-th century AD. (Vol. 1, pp. 487-497). Aarhus: Arhus University Press [in English].

Rousyaeva, A.S. (2010). Sanctuaries in the Context of the Cultural and Historical Development of Olbia Pontica. In Petropoulos, E.K. \& Maslennikov, A.A. (Ed.), Ancient Sacral Monuments in the Black Sea (pp. 63-92). Thessaloniki [in English].

Saldern, A., Nolte, B., La Baume, P. \& Haevernick, T.E. (1974). Gläser der Antike. Sammlung Oppenländer. Hamburg [in Deutsch].

Shelov, D.B. (1975). Keramicheskie kleima iz Tanaisa III-I vv. do n.e. [Ceramic stamps from Tanais III-I centuries BC]. Moscow: Nauka [in Russian].

Skrzhinskaia, M.V. (2006). Stekliannye i pastovye izdeliia [Glass items]. Materialy po arkheologii, istorii i etnografii Tavrii. Drevneishii temenos Olvii Pontiiskoi. Supplementum 2, 206-208 [in Russian].

Skudnova, V.M. (1988). Arkhaicheskii nekropol Olvii [Archaic necropolis of Olbia ]. Leningrad: Iskusstvo [in Russian].

Stern, E.M. (1999). Ancient Glass in Athenian Temple Treasures. Journal of Glass Studies. 41, 19-50 [in English].

Weinberg, G.D. (1969). Glass manufacture in the Hellenistic Rhodes. Archaiologikon Deltion, 24, 143-151 [in English].

\section{Anzhelika Kolesnychenko}

(Institute of Archaeology of the National Academy of Science of Ukraine, Kyiv, Ukraine)

ORCID: https://orcid.org/0000-0002-4598-5929

\section{Olbia Glass Vessels Made Using Core-Formed Technique}

Vessels made using the core-formed technique were coming to the main Greek centers of the Northern Black Sea region, especially to Olbia and Panticapaeum, in the $6^{\text {th }}-$ the $1^{\text {st }}$ century BC. About 280 vials made using the core-formed technique were found in Olbia. This assemblage is the largest on the northern coast of the Pontus.

The Olbia assemblage reflects the history of three consecutive Mediterranean core-formed glass industries. The most common form of the core-formed vessel in Olbia was alabastrum (108 items). In addition, 50 amphoriskoi, 10 aryballoi, 14 oinochoae, 2 unguentaria, and one hydriske are represented. The other items are very fragmented, and this prevents their typological attribution.

The core-formed vessels were coming to Olbia from the last quarter of the $6^{\text {th }}$ century $\mathrm{BC}$ to the beginning of the $1^{\text {st }}$ century AD. Most of the strictly dated vessels, just as in quantitative aspect, so in terms of typological diversity are known for the period of the last quarter of the $6^{\text {th }}$ century BC - first quarter of the $5^{\text {th }}$ century BC. The absolute majority of the vessels belong to the $5^{\text {th }}$ century BC. However, there are fewer strictly dated vessels here; as a rule, they can be dated only to one century in general. The group of vessels of the second half of the $5^{\text {th }}$ century BC allows assuming a certain decrease in the amount of core-formed vials coming into the city. The decrease is also recorded on the materials of the $4^{\text {th }}-3^{\text {rd }}$ century BC. From the middle of the $3^{\text {rd }}$ century $\mathrm{BC}$, there was their almost complete disappearance, only a few items are dated to the $1^{\text {st }}$ century $\mathrm{BC}$ - the beginning of the $1^{\text {st }}$ century $\mathrm{AD}$. This situation shows the general development of Olbia. 
The vessels were found in the following contexts: funeral, temple-sacral, public, and housing. Findings in housing contexts are rare. Only the Lower City (NGS) gave about 20 fragments. It can be explained by a larger area of the excavation site. The vials were found in the tombs of Olbia inhabitants from the $4^{\text {th }}$ to the $1^{\text {st }}$ century BC. They were systematically used in the burial ritual.

In the temple-sacral contexts, the fragments of core-formed vessels were found in the temenoi of Olbia: Southern, Eastern, and Western. The biggest assemblage of core-formed vessels (29 items) was found in Southern temenos, which was presumably related to the cult of Aphrodite. The total number of core-formed vessels from temenoi exceeds the number of such items originating from public and housing contexts and is inferior only to the number of vessels found in the necropolis.

Olbia is a model site for the study of the ancient glass of the North Black Sea region.

Keywords: Northern Black Sea region, Mediterranean, temenos, context, core-formed technique 


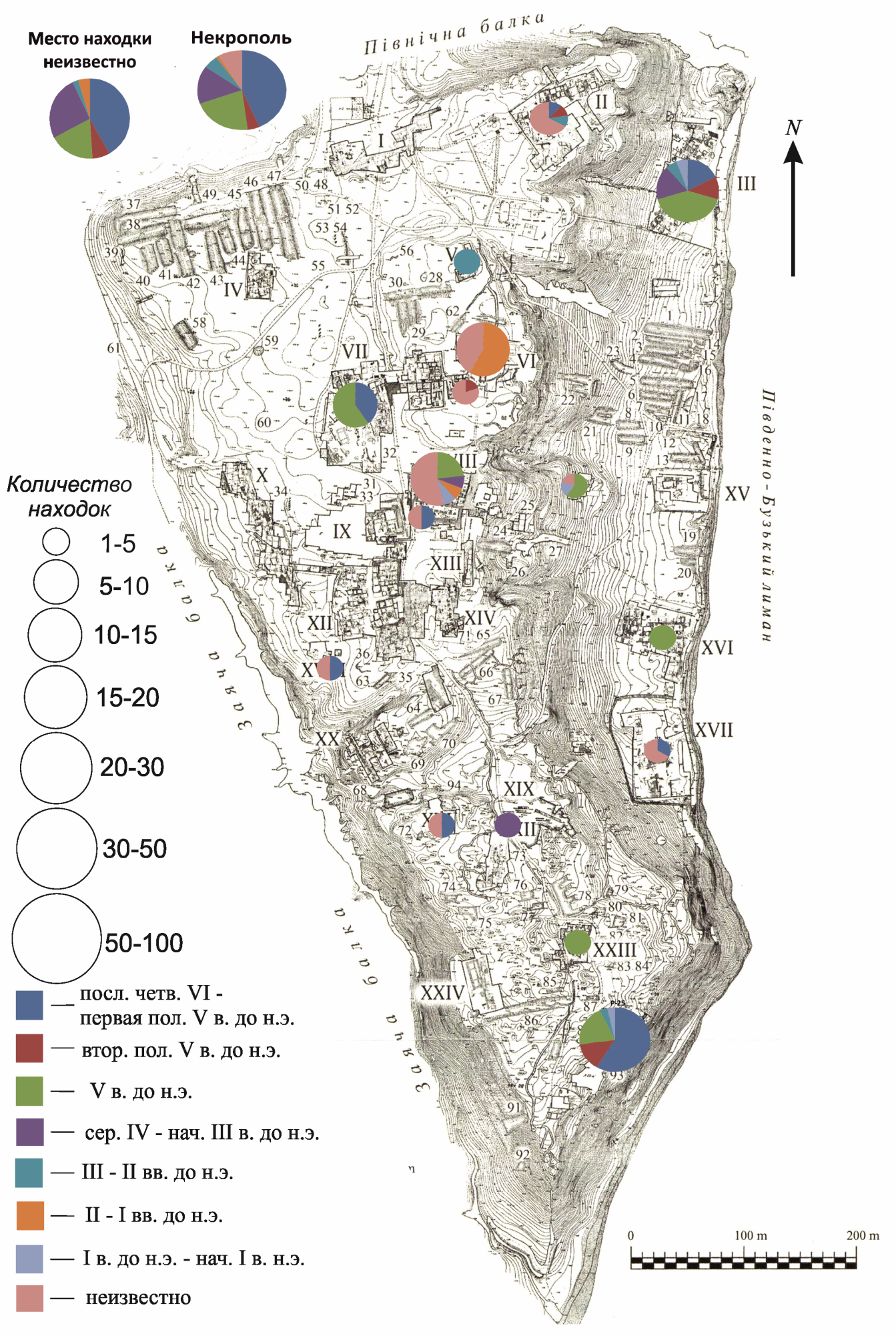

Рис. 1. План Ольвии с количественным распределением находок во временных диапазонах (топографический план по: Крижицький, Каряка 2017). 


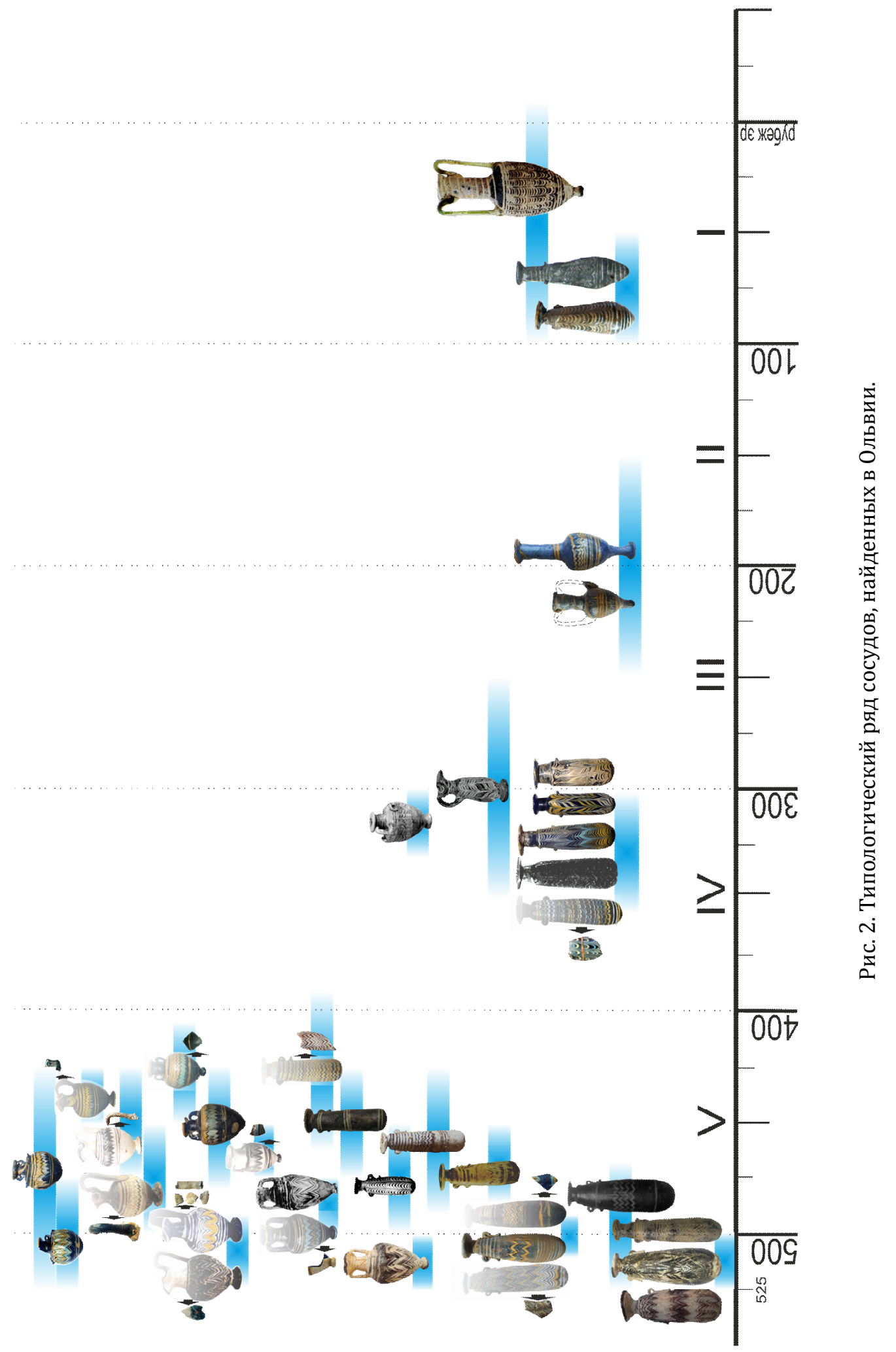




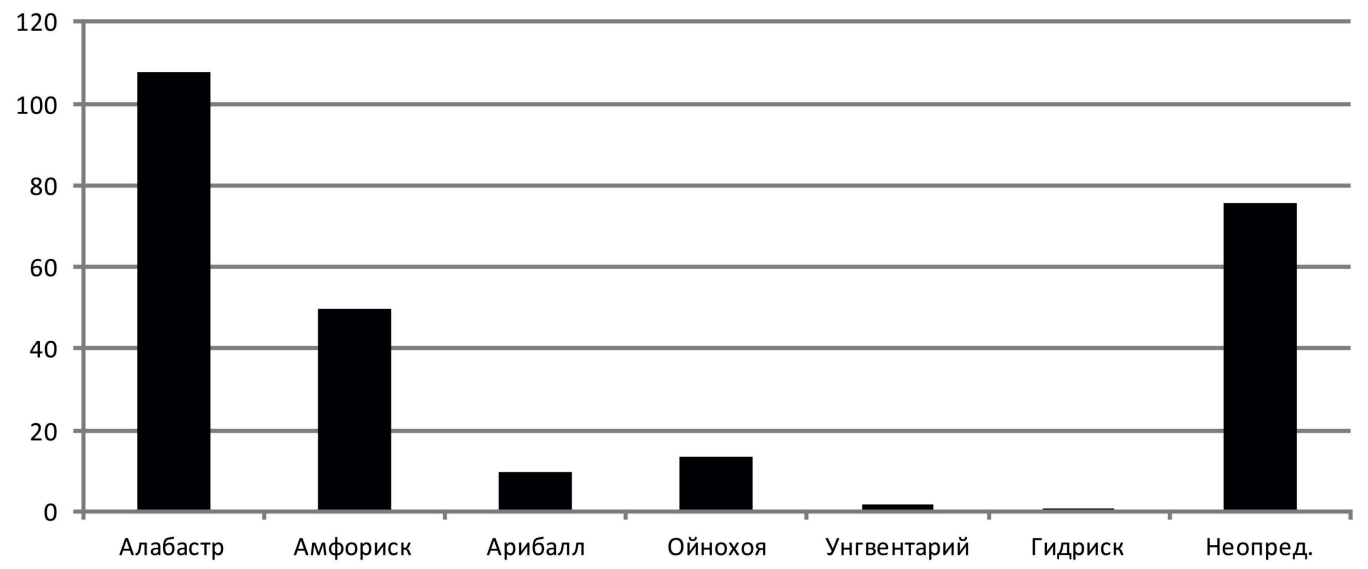

Рис. 3. Формы сосудов в количественном соотношении.

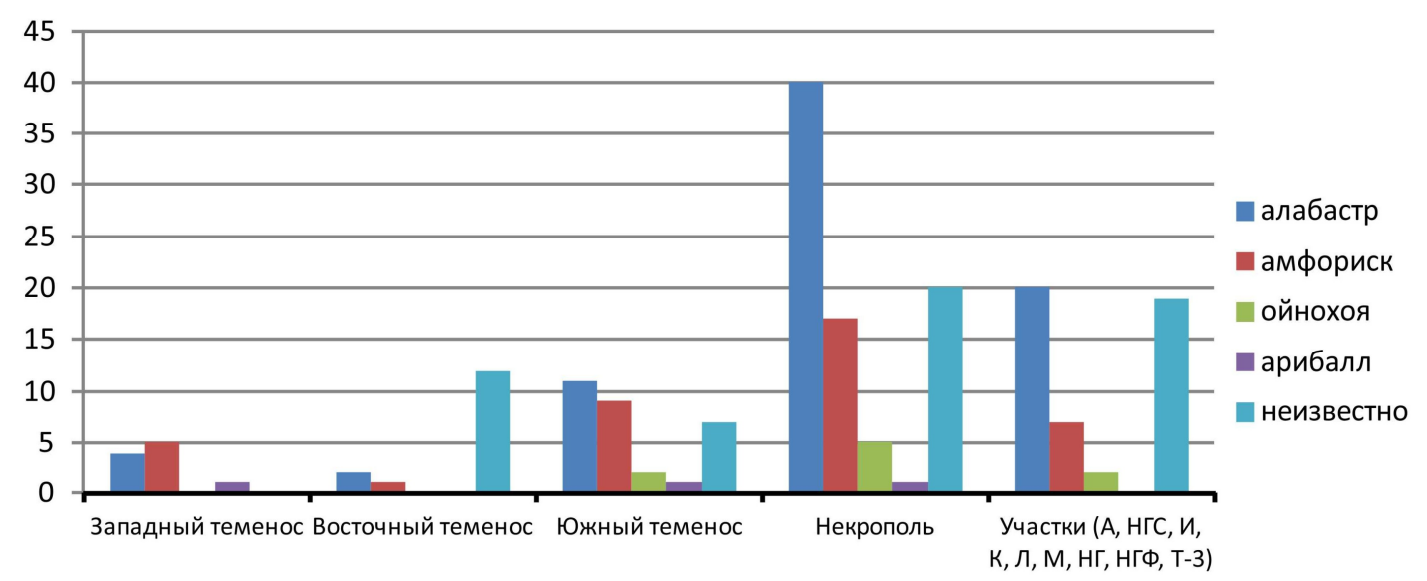

Рис. 4. Распределение форм сосудов по контекстам.

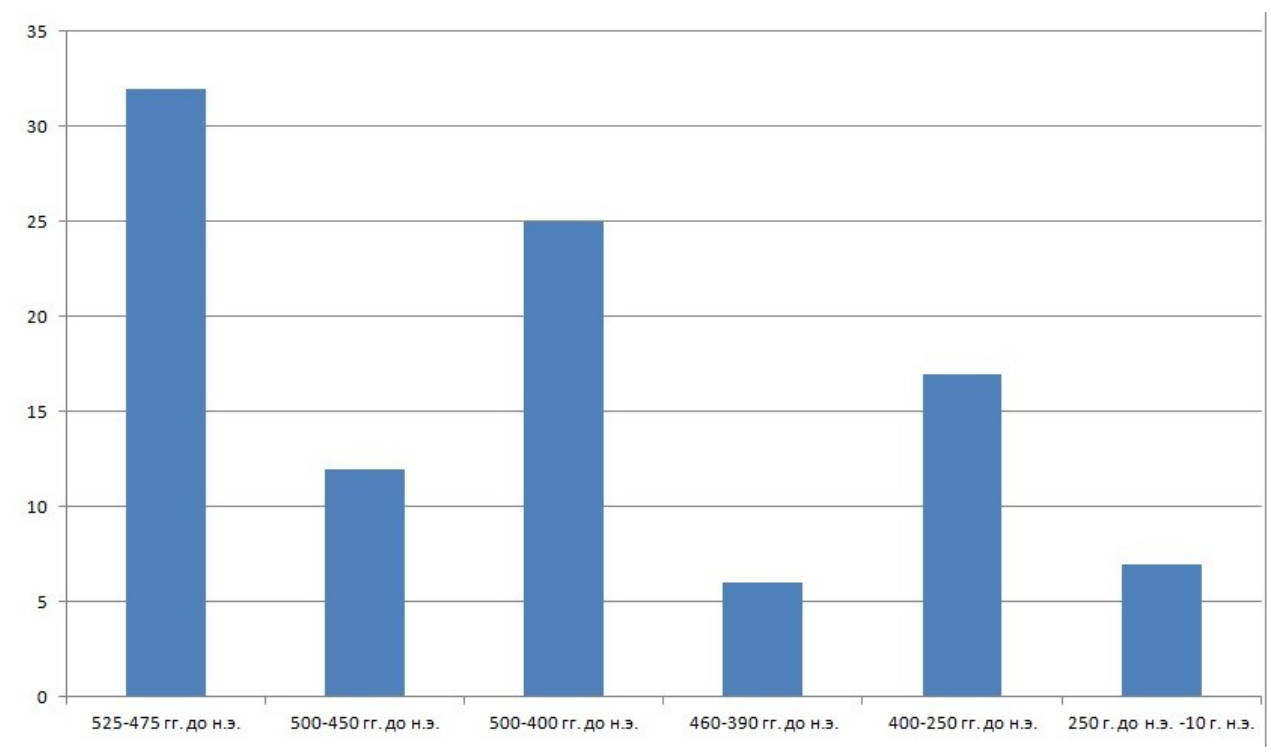

Рис. 5. Динамика использования сосудов. 